\title{
Current Technology Landscape for Collecting Hand Anthropometric Data
}

\author{
Susan L. SOKOLOWSKI ${ }^{\star 1}$, Linsey GRIFFIN², Sandeep CHANDRASEKHAR ${ }^{1}$ \\ ${ }^{1}$ University of Oregon, Portland OR, USA; \\ 2 University of Minnesota, St. Paul MN, USA \\ DOI: $10.15221 / 18.142 \quad$ http://dx.doi.org/10.15221/18.142
}

\begin{abstract}
Historically, three methods have been used to collect hand anthropometric data. The oldest and most known method was developed in the late 1800's, where researchers used rulers, calipers and tape measures to manually collect data from a subject's landmarked hand, or from obvious parts of the limb that can be measured without landmarks (e.g., wrist circumference). The second method uses 2D imagery that is collected from the subject and then measured manually/digitally with rulers or calipers. A variety of devices can collect this type of imagery; including photo boxes, x-ray machines, flatbed scanners and photo copiers. These tools are convenient for collecting hand data, but can be limiting as they only collect one flat view of the hand, at one time. Over the last ten years, 3D scanning technology has been adopted for hand studies because of its' ability to collect data quickly, and with better accuracy, as there are less steps and human error involved. 3D scanning allows researchers to collect data of an entire body part at one time, where it can be analyzed digitally beyond straight measures and circumferences. There are three types of scanners available in the market to collect hand anthropometric data, they include: 1) ones made specifically for hand scanning, 2) foot scanners and 3) hand held/mobile/tablet devices. But which 3D scanner should you select for your hand research? This can be an overwhelming decision, as there are so many options, and knowing what to look for can be confusing and quite difficult to find. Through experimentation with different equipment and hand studies, the researchers, developed a framework of key attributes that are important to selecting 3D scanners. They include: vendor/location, hand-held compatibility, scanner size, weight, envelope, supporting weight, price; along with scanner technology, timing, resolution, color capture, and file saving. Through this research, the authors desire to help others who want to purchase and conduct hand anthropometric research, to be more informed so can use their resources effectively and efficiently to have success with their work.
\end{abstract}

Keywords: Hands, Anthropometry, 3D Scanning, Technology

\section{Introduction}

Sokolowski and Griffin cumulatively have over thirty-five years of experience leading anthropometric studies related to product design and sizing. They have conducted work in this field with major manufacturers, start-ups and now respectively at the Universities of Oregon and Minnesota. They are also research collaborators, working on several projects related to Personal Protective Product (PPE), involving hand anthropometry. The impetus of this research came out of necessity, as they are both responsible for developing modern laboratory spaces at their universities, including 3D scanning capabilities, with constrained resources. Given the saturation of the 3D scanning equipment landscape, a selection framework was needed to help make decisions on what tools are most relevant and effective when conducting studies. This paper will review rationale, a selection framework and findings when the framework is applied to 3D scanning equipment available in the current marketplace.

\section{Background and Framework}

\subsection{Historical and current methods to collect hand anthropometric data}

Historically, three methods have been used to collect hand anthropometric data. The oldest and most known method was developed in the late 1800's, where researchers used rulers, calipers and tape measures to manually collect data from a subject's landmarked hand, or from obvious parts of the limb that can be measured without landmarks (e.g., wrist circumference) [1, 2]. The second method uses 2D imagery that is collected from the subject and then measured manually/digitally with rulers or calipers [2, 3]. A variety of devices can collect this type of imagery; including photo boxes, $x$-ray machines, flatbed scanners and photo copiers [2]. These tools are convenient for collecting hand data, but can be limiting as they only collect one flat view of the hand, at one time [2]. Over the last ten years, 3D scanning

*Sports Product Design - University of Oregon, 70 NW Couch Street, Portland, OR 97209 USA

(e-mail: ssokolow@uoregon.edu). 
technology has been adopted because of its' ability to collect data quickly, and with better accuracy as there are less steps and human error involved [2]. 3D scanning allows researchers to collect data of an entire body part at one time, where it can be analyzed digitally beyond straight measures and circumferences [2, 4].

\subsection{Current hand scanning technology challenges}

There are three types of scanners available in the market to collect hand anthropometric data, they include: 1) ones made specifically for hand scanning, 2) foot scanners and 3) hand held/mobile/tablet devices. There are fewer hand-specific 3D scanning devices in the marketplace, however, foot scanners are readily available and in most cases are appropriate. Sometimes, these devices can be limiting, where they may not have a large enough scanning envelope for bigger hands and prevent task-related anthropometric posing (e.g., grasping and pulling) from being captured. Today, technology start-ups are popping-up and competing with new products that are portable and/or hand held device compatible - which are ideal for unique hand posing and the inclusion of objects/props where the researcher desires to learn about grip formation and hand positioning of specific users (e.g., firefighters and athletes), during specialized tasks - as they do not have a restricted scanning envelope. They also allow data to be collected from users anywhere, which is helpful when subjects do not live near a specified research facility.

The scan equipment landscape as related to hand anthropometry is in great flux today. For many years the market had few vendors that manufactured and distributed equipment. Scanners came at a very high cost. The costs forced researchers, especially ones from academia to choose between a large format 3D body scanner or a foot/hand scanner for their laboratories. The constraint also effected the research landscape, as there are fewer studies with regards to hand anthropometry, compared to full body. But with the larger landscape of 3D scanners, which one should you select for your hand anthropometric research? This can be an overwhelming decision, as there are so many options, and knowing what to look for can be confusing and quite difficult to find. When the attributes of a piece of equipment are not researched thoroughly, the quality of the research could be greatly affected by shortcomings of the device used.

\subsection{D hand scanner rationale}

3D body scanners can be quite powerful tools for researchers that conduct anthropometric studies. In the case of hand studies, when the 3D image is appropriately captured, a multitude of information can be gathered to learn about its' size, shape, and how to better design performing products - like gloves, tools and medical instruments. However, not all 3D scanners are the same, and the data they collect can be quite variable. Through pilot studies with different scanning equipment, the researchers established minimum guidelines (Table 1) of what a 3D scanner must do, in order to effectively collect hand anthropometric data.

Table 1. Minimum 3D scanner guidelines for hand anthropometric studies.

\begin{tabular}{|c|c|}
\hline Current Challenges Observed & 3D Hand Scanner Minimum Guidelines \\
\hline $\begin{array}{l}\text { Some scanners cannot capture larger hands, } \\
\text { including the wrist, because the scanning } \\
\text { envelope is not big enough. }\end{array}$ & $\begin{array}{l}\text { Ability to capture the entire hand and wrist of } \\
\text { any sized subject. }\end{array}$ \\
\hline $\begin{array}{l}\text { Some devices cannot capture darker skin } \\
\text { colors. }\end{array}$ & Ability to capture any skin color. \\
\hline $\begin{array}{l}\text { Some scanners cannot capture the subject } \\
\text { holding an object, in an ergonomic position as } \\
\text { the scanning envelope is not big enough. }\end{array}$ & $\begin{array}{l}\text { Ability to capture the entire hand and wrist in } \\
\text { various task-related positions, which may } \\
\text { include holding other objects. }\end{array}$ \\
\hline $\begin{array}{l}\text { Some devices cannot capture finite hand/wrist } \\
\text { details. }\end{array}$ & Ability able to see the skin folds and wrinkles. \\
\hline $\begin{array}{l}\text { Much like skin color, some scanners cannot } \\
\text { capture landmark colors or color contrasts. }\end{array}$ & $\begin{array}{l}\text { Ability to see flat sticker/pen landmarks that are } \\
\text { used for anthropometric measurement } \\
\text { gathering. }\end{array}$ \\
\hline $\begin{array}{l}\text { Some scanning software do not save files that } \\
\text { can be opened in a variety of software } \\
\text { packages to measure and design from. }\end{array}$ & $\begin{array}{l}\text { Ability to reuse the data set across different } \\
\text { software packages to measure and design with. }\end{array}$ \\
\hline $\begin{array}{l}\text { Heavy scanners are impossible to pack up, } \\
\text { carry and take on flights to capture data from } \\
\text { subjects that are not local to the researcher's } \\
\text { laboratory. }\end{array}$ & $\begin{array}{l}\text { Ability to be portable, ideally under } 11 \mathrm{~kg}(25 \mathrm{lb}) \\
\text { - so it can be packed in carry-on luggage for air } \\
\text { travel. }\end{array}$ \\
\hline
\end{tabular}




\subsection{Selection attributes}

With the guidelines, the researchers developed the 3D Hand Scanning Attributes Framework (3D HSAF) to assess individual scanners. The framework was devised to provide researchers a checklist of critical 3D scanner attributes needed to collect appropriate hand data. These attributes are not weighted or prioritized, because every researcher will have different priorities for their work. These are merely levers that need to be considered in totality when making a scanner purchase. They are also the questions any scan vendor should be able to answer clearly when approached about their equipment. Key attributes include: vendor/location, hand-held compatibility, scanner size, weight, envelope, supporting weight, price; along with scanner technology, timing, resolution, color capture, and file saving (Fig 1).

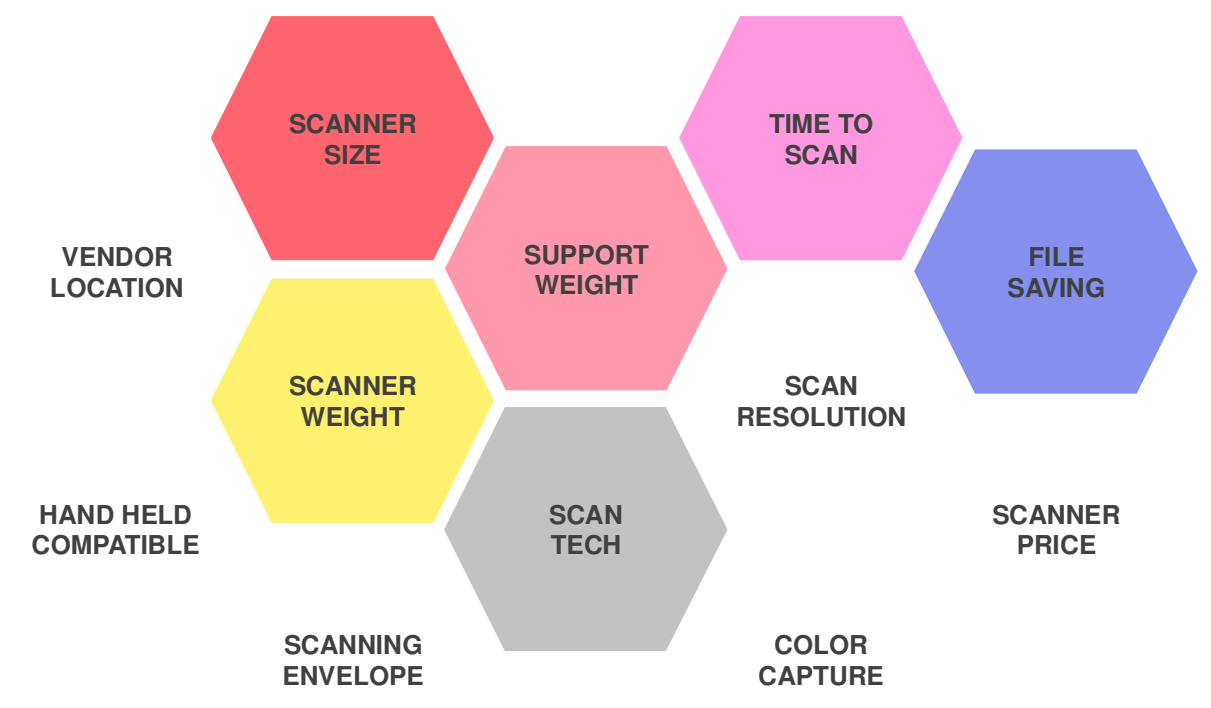

Fig. 1. 3D Hand Scanning Attributes Framework (3D HSAF).

Ultimately, through the 3D HSAF, the authors desire to help others who want to purchase and conduct hand anthropometric research, to be more informed so can use their resources effectively and efficiently to have success with their work.

Furthermore, the attributes of the 3D HSAF are defined in Table 2.

Table 2. 3D HSAF definitions (alphabetically).

\begin{tabular}{|l|l|l|}
\hline Attribute & Definition & Importance to Researchers \\
\hline $\begin{array}{l}\text { Color } \\
\text { Capture }\end{array}$ & $\begin{array}{l}\text { The ability for the 3D scan to } \\
\text { be collected in color } \\
\text { (including texture map). }\end{array}$ & $\begin{array}{l}\text { Color and texture are important when collecting } \\
\text { landmarks, wrinkles/creases and skin color. }\end{array}$ \\
\hline File Saving & $\begin{array}{l}\text { The suffix portion of the } \\
\text { scan file name, when saved. }\end{array}$ & $\begin{array}{l}\text { The file format is important, because the scan will } \\
\text { likely to be opened in other software programs for } \\
\text { analysis and CAD. Commonly used file names are } \\
\text { OBJ and STL. There are many others. }\end{array}$ \\
\hline $\begin{array}{l}\text { Hand-Held } \\
\text { Compatibility }\end{array}$ & $\begin{array}{l}\text { Ability for the scanner to be } \\
\text { hand-held as a small } \\
\text { tool/wand, run through the } \\
\text { camera of a hand-held } \\
\text { device or to affix as a scan } \\
\text { accessory to a hand-held } \\
\text { device. }\end{array}$ & $\begin{array}{l}\text { This is where many start-ups are developing new 3D } \\
\text { scanners. These scanners are more economical, } \\
\text { quite relevant to hand scanning needs and portable. }\end{array}$ \\
\hline $\begin{array}{l}\text { Location of } \\
\text { Scanner } \\
\text { Vendor }\end{array}$ & $\begin{array}{l}\text { The place where the 3D } \\
\text { scanner was manufactured } \\
\text { and ships from. }\end{array}$ & $\begin{array}{l}\text { Many scan manufacturers will not ship overseas and } \\
\text { if they do, it will be costly. Working with vendors that } \\
\text { are in-country may be most cost effective. }\end{array}$ \\
\hline
\end{tabular}




\begin{tabular}{|c|c|c|}
\hline $\begin{array}{l}\text { Scanning } \\
\text { Envelope }\end{array}$ & $\begin{array}{l}\text { The capture space of the } \\
\text { scanner, including length, } \\
\text { width and height. }\end{array}$ & $\begin{array}{l}\text { It is important to know the limits of the scan envelope, } \\
\text { as subjects that have larger hands (e.g., basketball } \\
\text { players) or are being scanned in task-related poses } \\
\text { with objects (e.g., fire fighters with an item of } \\
\text { equipment) may not fit in the envelope and data } \\
\text { would be incomplete/not useable. }\end{array}$ \\
\hline $\begin{array}{l}\text { Scanner } \\
\text { Price }\end{array}$ & $\begin{array}{l}\text { The total price to purchase } \\
\text { the scanner. }\end{array}$ & $\begin{array}{l}\text { Academic researchers have very limited budgets, } \\
\text { unless they are able to bring in additional grant } \\
\text { funding to build-up their laboratories. This is } \\
\text { especially true in the apparel and product disciplines, } \\
\text { as there is often competing needs for resources (e.g., } \\
\text { machinery/supplies for students, lab space, } \\
\text { software). }\end{array}$ \\
\hline $\begin{array}{l}\text { Scan } \\
\text { Resolution }\end{array}$ & The clarity of the scan. & $\begin{array}{l}\text { The higher the resolution, the clearer the scan and } \\
\text { ability to analyze it. }\end{array}$ \\
\hline Scanner Size & $\begin{array}{l}\text { The length, width and height } \\
\text { dimensions of the scanner. }\end{array}$ & $\begin{array}{l}\text { Size is important when shipping and delivery. It is } \\
\text { also needed for understanding how much lab space } \\
\text { is required to operate it, and transporting to other } \\
\text { locations for data collection (if feasible). }\end{array}$ \\
\hline $\begin{array}{l}\text { Scan } \\
\text { Technology }\end{array}$ & $\begin{array}{l}\text { The method of 3D scan } \\
\text { capture (e.g., photogram- } \\
\text { metry, structured light, } \\
\text { LASER). }\end{array}$ & $\begin{array}{l}\text { Knowledge of the technology helps inform to how the } \\
\text { scan environment should be set-up (e.g., lighting). It } \\
\text { also may effect scan quality. }\end{array}$ \\
\hline $\begin{array}{l}\text { Scanner } \\
\text { Weight }\end{array}$ & $\begin{array}{l}\text { The total weight of the } \\
\text { scanner. }\end{array}$ & $\begin{array}{l}\text { For hand research, if the device can be portable - } \\
\text { under } 11 \mathrm{~kg}(25 \mathrm{lb}) \text { - it can be packed in carry-on } \\
\text { luggage for air travel. Scanners under } 4.5 \mathrm{~kg}(10 \mathrm{lbs}) \\
\text { are even more favorable, as multiple units can be } \\
\text { transported together for larger studies. }\end{array}$ \\
\hline $\begin{array}{l}\text { Support } \\
\text { Weight }\end{array}$ & $\begin{array}{l}\text { The maximum body weight } \\
\text { that can be placed upon the } \\
\text { scanner before it is } \\
\text { damaged (e.g., cracked). }\end{array}$ & $\begin{array}{l}\text { This is important for studies where the hand is } \\
\text { scanned with heavy objects or put under force. For } \\
\text { hand-held devices, this is not an issue. }\end{array}$ \\
\hline Time to Scan & $\begin{array}{l}\text { The amount of time from } \\
\text { start to finish needed to } \\
\text { capture one 3D scan. }\end{array}$ & $\begin{array}{l}\text { For large studies, every second counts, so faster } \\
\text { scanners help facilitate the work. There is also less } \\
\text { subject movement captured. }\end{array}$ \\
\hline
\end{tabular}

\section{Methodology}

The purpose of this research was to use the newly developed 3D HSAF, to understand the current 3D scanner technology landscape, related to hand anthropometry research. To insure consistency of knowledge gathering, one point of contact was appointed to reach out to vendors, to collect data. Through marketing materials from the 2018 3DBody.Tech Conference and Google searches, vendors throughout North America, Europe and Asia were identified. A three pronged approach to obtaining information was used. First, initial data was collected through the specified vendor's website. Secondly, connections were made over via email, as in most cases scanner attributes were never all present on the vendor's website. If the email communication was not successful or a reply was not received within 48 hours, follow-up telephone calls with the vendor's sales department were made. The calls were also used to clarify additional questions. All data were inputted to a spreadsheet.

\section{Results}

Twenty-four vendors from nine countries were contacted, and provided information for this study. Additional vendors were contacted, but they were not included in the results as they did not reply or provide enough information to have a clear explanation of their products. Through the initial research phase of finding and reviewing vendor websites, there was an obvious lack of publicly available attribute documentation, including important operating, user features and price. Once emails were sent, the 
attributes were documented for each vendor/scanning device. However, there were some vendors contacted that did not reply with clear information, and those correspondences were followed up with a telephone call. Overall, the researchers found great inconsistency with how vendors listed their measures, including weights, envelope size and resolution. All results were converted to be in the same scale, with metric and imperial results. Additionally, many vendors were not able to provide evidence (e.g. research studies or published papers) to support claims of their products. Based upon the 3D HSAF, the results of the study are presented (Tables 3 to 10 ).

\subsection{Location of 3D hand scanner vendor}

Table 3 presents the twenty-four vendors in alphabetical order, and where they manufactured and ship their 3D scanners from. Some companies may have other satellite offices that were not noted on their website or during the data collection process.

Table 3. City and country location of 3D hand scanner vendors.

\begin{tabular}{|l|l|}
\hline Vendor Name & City/Country \\
\hline 3D Footbank by Dream GP & Osaka, Japan, Wood Dale, Illinois USA \\
\hline 3DMD & Atlanta, Georgia USA \\
\hline Anatomi Metrix & Montreal, Canada \\
\hline Aetrex Technology & Teaneck, New Jersey USA \\
\hline Artec & $\begin{array}{l}\text { Luxembourg, + subsidiaries in Palo Alto, California, } \\
\text { USA and Moscow, Russia }\end{array}$ \\
\hline FlicFit & Meguro-ku, Japan \\
\hline Global Inspection Solutions/3D3 Solutions & Portland, Oregon USA \\
\hline Hewlett-Packard (HP) & Palo Alto, California USA (+27 US subsidiaries) \\
\hline Human Solutions & Kaiserslautern, Germany \& Raleigh, North Carolina \\
& USA \\
\hline IBV: Instituto de Biomecánica de Valencia & Valencia, Spain \\
\hline Leica Geosystems & Heerbrugg, Switzerland \& Norcross, Georgia USA \\
\hline Netvirta & Boston, Massachusetts USA \& Singapore \\
\hline Occipital & San Francisco, California \& Boulder, Colorado USA \\
\hline Paromed & Queensland, Australia \& Neubeuern, Germany \\
\hline Precision 3D & Weston-Super-Mare, United Kingdom \\
\hline Scandy LLC & Elmwood, Louisiana USA \\
\hline Shenzhen 3DOE Technology & Shenzhen, Guangdong, China \\
\hline Shining 3D & $\begin{array}{l}\text { Hangzhou, China, Stuttgart, Germany \& San } \\
\text { Francisco USA }\end{array}$ \\
\hline STT Systems & San Sebastián, Spain \\
\hline TechMed3D & Quebec City, Canada \\
\hline Thor3D & Moscow, Russia \\
\hline Trnio & San Francisco, California USA \\
\hline Volumental & Stockholm, Sweden \\
\hline Vorum & Vancouver, British Columbia Canada \\
\hline & \\
\hline
\end{tabular}

\subsection{Hand-held compatibility and scan technology}

Of the twenty-four vendors, only $8 \%$ manufactured hand-specific 3D scanners. Forty-six percent of the vendors produced scanners that were hand-held (including tablet/phone). The ability for scanners to be hand-held is quite relevant to hand scanning studies, as they are portable and can allow for variable scanning envelopes (Table 6). The method of 3D scan capture (e.g., photogrammetry, structured light, LASER) is also presented (Table 4). Knowledge of the technology used helps inform to how the scan environment should be set-up (e.g., lighting and wall coloring). It also may effect scan quality. 
Table 4. 3D scanner hand-held (including tablet/phone device) capability and capture technology, by vendor.

\begin{tabular}{|l|l|l|}
\hline Vendor Name & Yes or No & Capture Technology \\
\hline 3D Footbank by Dream GP (foot scanner) & No & LASER light \\
\hline 3DMD (hand scanner) & No & Stereophotogrammetry \\
\hline Anatomi Metrix (hand scanner) & No & LASER light \\
\hline Aetrex Technology (foot scanner) & No & Structured light \\
\hline Artec (multi-use hand held scanner) & Yes & Structured light \\
\hline FlicFit (foot scanner) & Yes & LASER light \\
\hline $\begin{array}{l}\text { Global Inspection Solutions/3D3 Solutions } \\
\text { (multi-use scanner) }\end{array}$ & No & Structured light \\
\hline Hewlett-Packard (foot scanner) & No & Structured light \\
\hline Human Solutions (foot scanner) & No & LASER light \\
\hline $\begin{array}{l}\text { IBV: Instituto de Biomecánica de Valencia } \\
\text { (foot scanner) }\end{array}$ & No & LASER light \\
\hline Leica Geosystems (multi-use scanner) & No & LASER light \\
\hline Netvirta (multi-use hand held scanner) & Yes & Photogrammetry \\
\hline Occipital (multi-use hand held scanner) & Yes & Structured light \\
\hline Paromed (foot scanner) & Yes & LASER or Structured light \\
\hline Precision 3D (foot scanner) & Yes & Stereophotogrammetry \\
\hline $\begin{array}{l}\text { Shenzhen 3DOE Technology (foot } \\
\text { scanner) }\end{array}$ & No & LASER light \\
\hline Shining 3D (multi-use hand held scanner) & Yes & No \\
\hline STT Systems (foot scanner) & Yes & LASER light \\
\hline $\begin{array}{l}\text { TechMed3D (multi-use hand held } \\
\text { scanner) }\end{array}$ & Yes & White light \\
\hline Thor3D (multi-use hand held scanner) & Yes & Structured light \\
\hline Trnio (multi-use hand held scanner) & No & Shotogrammetry \\
\hline Volumental (foot scanner) & Structured light \\
\hline Vorum (multi-use hand held scanner) & \\
\hline
\end{tabular}

\subsection{Scanner size and weight}

Table 5 presents the size (millimeters/inches) of each scanner and their weights (kilograms/pounds). All results were converted for consistency, as vendors shared their information in a wide array of units. The smallest scanners are from: Netvirta, Occipital, Scandy LLC and Trnio - they are all hand-held mobile device systems. The largest scanners were the 3DMD hand system and Precision 3D. The lightest scanners were from Netvirta, Occipital, Scandy LLC and Trnio, as they are operated on a mobile phones between 0.1 to $0.2 \mathrm{~kg}(0.2$ to $0.4 \mathrm{lb})$. The heaviest scanner was STT Systems at $128 \mathrm{~kg}$ (282.2 lb).

Table 5. 3D scanner size and weight, by vendor.

\begin{tabular}{|l|l|l|}
\hline Vendor Name & Size & Weight \\
\hline 3D Footbank by Dream GP & $610 \times 457 \times 203 \mathrm{~mm}$ & $\begin{array}{l}12 \mathrm{~kg} \\
(26.4 \mathrm{lb})\end{array}$ \\
\hline 3DMD & $(24 \times 18 \times 8 \mathrm{in})$ & 4.5 to $5.5 \mathrm{~kg}$ \\
(hand system) & $1940 \times 1760 \times 1120 \mathrm{~mm}$ & $(10$ to $15 \mathrm{lb})$ \\
\hline Anatomi Metrix & $(76 \times 69 \times 45 \mathrm{in})$ & Not available \\
\hline Aetrex Technology & Information not available & $8.2 \mathrm{~kg}$ \\
& $1036 \times 719 \times 142 \mathrm{~mm}$ & $(18.0 \mathrm{lb})$ \\
\hline
\end{tabular}




\begin{tabular}{|c|c|c|}
\hline Artec & $\begin{array}{l}190 \times 140 \times 130 \mathrm{~mm} \text { to } 262 \times 158 \times 64 \mathrm{~mm} \\
(7.5 \times 5.5 \times 5.1 \text { in to } 10.3 \times 6.2 \times 2.5 \mathrm{in})\end{array}$ & $\begin{array}{l}0.9 \mathrm{~kg} \text { (all models) } \\
(1.9 \mathrm{lb})\end{array}$ \\
\hline FlicFit & $\begin{array}{l}775 \times 872 \times 257 \mathrm{~mm} \\
(30.5 \times 34.3 \times 10.2 \mathrm{in})\end{array}$ & $\begin{array}{l}30.0 \mathrm{~kg} \\
(66.1 \mathrm{lb})\end{array}$ \\
\hline $\begin{array}{l}\text { Global Inspection } \\
\text { Solutions/3D3 Solutions }\end{array}$ & $\begin{array}{l}165 \times 310 \times 455 \mathrm{~mm} \\
(6.5 \times 12.2 \times 17.9 \mathrm{in}) \\
\end{array}$ & $\begin{array}{l}11.3 \mathrm{~kg} \\
(25.0 \mathrm{lb})\end{array}$ \\
\hline Hewlett-Packard (HP) & $\begin{array}{l}740 \times 430 \times 320 \mathrm{~mm} \\
(29.1 \times 16.9 \times 12.6 \mathrm{in})\end{array}$ & $\begin{array}{l}26.0 \mathrm{~kg} \\
(57.3 \mathrm{lb})\end{array}$ \\
\hline Human Solutions & $\begin{array}{l}400 \times 400 \times 800 \mathrm{~mm} \\
(15.7 \times 15.7 \times 31.5 \mathrm{in})\end{array}$ & $\begin{array}{l}68 \mathrm{~kg} \\
(150 \mathrm{lb})\end{array}$ \\
\hline $\begin{array}{l}\text { IBV: Instituto de } \\
\text { Biomecánica de Valencia }\end{array}$ & $\begin{array}{l}350 \times 450 \times 450 \mathrm{~mm} \\
(13.8 \times 17.7 \times 17.7 \mathrm{in})\end{array}$ & $\begin{array}{l}4.6 \mathrm{~kg} \\
(10.1 \mathrm{lb})\end{array}$ \\
\hline Leica Geosystems & $\begin{array}{l}178.5 \times 120 \times 25.8 \mathrm{~mm} \\
(7.1 \times 4.7 \times 1 \mathrm{in})\end{array}$ & $\begin{array}{l}2.8 \mathrm{~kg} \\
(6.2 \mathrm{lb})\end{array}$ \\
\hline $\begin{array}{l}\text { Netvirta } \\
\text { (phone Ap) }\end{array}$ & $\begin{array}{l}138 \times 67 \times 7.3 \text { to } 160 \times 78 \times 8.1 \mathrm{~mm} \\
(5.4 \times 2.6 \times .01 \text { to } 6.3 \times 3.1 \times .32 \mathrm{in})\end{array}$ & $\begin{array}{l}\text { Between } 0.1 \text { to } 0.2 \mathrm{~kg} \\
(0.2 \text { to } 0.4 \mathrm{lb})\end{array}$ \\
\hline $\begin{array}{l}\text { Occipital } \\
\text { (affixes to an ipad) }\end{array}$ & $\begin{array}{l}119.2 \times 29 \times 28 \mathrm{~mm} \\
(4.7 \times 1.1 \times 1.1 \mathrm{in})\end{array}$ & $\begin{array}{l}0.1 \mathrm{~kg} \\
(0.2 \mathrm{lb})\end{array}$ \\
\hline Paromed & $\begin{array}{l}269 \times 320 \times 707 \mathrm{~mm} \\
(10.6 \times 12.6 \times 27.8 \mathrm{in})\end{array}$ & $\begin{array}{l}11.3 \mathrm{~kg} \\
(24.9 \mathrm{lb})\end{array}$ \\
\hline Precision 3D & $\begin{array}{l}1000 \times 1000 \times 250 \mathrm{~mm} \\
(39.4 \times 39.4 \times 9.8 \mathrm{in}) \\
\end{array}$ & $\begin{array}{l}35 \mathrm{~kg} \\
(77.2 \mathrm{lb})\end{array}$ \\
\hline $\begin{array}{l}\text { Shenzhen 3DOE } \\
\text { Technology }\end{array}$ & $\begin{array}{l}570 \times 390 \times 310 \mathrm{~mm} \\
(22.4 \times 15.4 \times 12.2 \mathrm{in})\end{array}$ & $\begin{array}{l}20.0 \mathrm{~kg} \\
(44.0 \mathrm{lb})\end{array}$ \\
\hline Shining 3D & $\begin{array}{l}248 \times 156 \times 48 \mathrm{~mm} \\
(9.8 \times 6.1 \times 1.9 \mathrm{in})\end{array}$ & $\begin{array}{l}0.8 \mathrm{~kg} \\
(1.8 \mathrm{lb})\end{array}$ \\
\hline STT Systems & $\begin{array}{l}550 \times 800 \times 670 \mathrm{~mm} \\
(21.7 \times 31.5 \times 26.4 \mathrm{in})\end{array}$ & $\begin{array}{l}128 \mathrm{~kg} \\
(282.2 \mathrm{lb})\end{array}$ \\
\hline TechMed3D & $\begin{array}{l}96 \times 140 \times 258 \mathrm{~mm} \\
(3.8 \times 5.5 \times 10.2 \mathrm{in})\end{array}$ & $\begin{array}{l}85 \mathrm{~kg} \\
(1.9 \mathrm{lb})\end{array}$ \\
\hline Thor3D & $\begin{array}{l}360 \times 250 \times 110 \mathrm{~mm} \\
(14.2 \times 9.8 \times 4.3 \mathrm{in})\end{array}$ & $\begin{array}{l}2.3 \mathrm{~kg} \\
(5.1 \mathrm{lb})\end{array}$ \\
\hline $\begin{array}{l}\text { Trnio } \\
\text { (phone Ap) }\end{array}$ & $\begin{array}{l}138 \times 67 \times 7.3 \text { to } 160 \times 78 \times 8.1 \mathrm{~mm} \\
(5.4 \times 2.6 \times .01 \text { to } 6.3 \times 3.1 \times .32 \mathrm{in})\end{array}$ & $\begin{array}{l}\text { Between } 0.1 \text { to } 0.2 \mathrm{~kg} \\
(0.2 \text { to } 0.4 \mathrm{lb})\end{array}$ \\
\hline Volumental & $\begin{array}{l}800 \times 800 \times 300 \mathrm{~mm} \\
(31.5 \times 31.5 \times 11.8 \mathrm{in})\end{array}$ & $\begin{array}{l}9.7 \mathrm{~kg} \\
(21.4 \mathrm{lb})\end{array}$ \\
\hline Vorum & $\begin{array}{l}15 \mathrm{~cm} \times \mathrm{NA} \times \mathrm{NA} \\
(5.9 \times \mathrm{NA} \times \mathrm{NA} \text { in) }\end{array}$ & $\begin{array}{l}0.9 \mathrm{~kg} \\
(2.0 \mathrm{lb})\end{array}$ \\
\hline
\end{tabular}

\subsection{Scanning envelope and supported weight}

The best way to define the scanning envelope is by knowing its' length, width and height. The envelope is the area that gets captured by the scanner. By just having one dimension (e.g., height), it is not useful, as the researcher needs to know how wide and long the object can be, in order to be completely scanned. When vendors were asked about the scanning envelope attribute of their scanners, they shared quite inconsistent information. Many vendors shared only 1 or 2 of the envelope dimensions. Table 6 presents scanning envelopes along with supported weight when relevant - as the hand held devices do not have this measurement limitation. 
Table 6. 3D Scanner envelope and supported weight, by vendor.

\begin{tabular}{|c|c|c|}
\hline Vendor Name & Scanning Envelope & Supported Weight \\
\hline 3D Footbank by Dream GP & $\begin{array}{l}305 \text { to } 381 \mathrm{~mm} \text { high } \\
\text { (12 to } 15 \mathrm{in})\end{array}$ & $\begin{array}{l}\text { Up to } 90.7 \mathrm{~kg} \\
(200 \mathrm{lb})\end{array}$ \\
\hline $\begin{array}{l}\text { 3DMD } \\
\text { (hand system with } 5 \text { camera units) }\end{array}$ & $\begin{array}{l}\text { Variable depending on } \\
\text { camera configuration }\end{array}$ & $\begin{array}{l}\text { Not Applicable } \\
\text { (no platform) }\end{array}$ \\
\hline Anatomi Metrix & Information not available & $\begin{array}{l}\text { Up to } 50 \mathrm{~kg} \\
(110.2 \mathrm{lb})\end{array}$ \\
\hline Aetrex Technology & $\begin{array}{l}360 \times 360 \mathrm{~mm} \\
(14.2 \times 14.2 \mathrm{in})\end{array}$ & $\begin{array}{l}\text { Not Applicable } \\
\text { (hand held) }\end{array}$ \\
\hline Artec & $\begin{array}{l}90 \times 70 \mathrm{~mm} \\
(3.5 \times 2.8 \mathrm{in})\end{array}$ & $\begin{array}{l}\text { Not Applicable } \\
\text { (hand held) }\end{array}$ \\
\hline FlicFit & $\begin{array}{l}300 \mathrm{~mm} \text { high } \\
(11.8 \mathrm{in})\end{array}$ & $\begin{array}{l}\text { Up to } 200 \mathrm{~kg} \\
(441 \mathrm{lb})\end{array}$ \\
\hline $\begin{array}{l}\text { Global Inspection Solutions/3D3 } \\
\text { Solutions }\end{array}$ & $\begin{array}{l}165 \mathrm{~mm} \text { high } \\
(6.5 \mathrm{in})\end{array}$ & $\begin{array}{l}\text { Not Applicable } \\
\text { (hand held) }\end{array}$ \\
\hline Hewlett-Packard (HP) & $\begin{array}{l}400 \times 200 \times 180 \mathrm{~mm} \\
(15.7 \times 7.9 \times 7.1 \mathrm{in})\end{array}$ & $\begin{array}{l}\text { Up to } 136.1 \mathrm{~kg} \\
(300 \mathrm{lb})\end{array}$ \\
\hline Human Solutions & $\begin{array}{l}180 \mathrm{~mm} \text { high } \\
\text { (7.1 in) }\end{array}$ & $\begin{array}{l}\text { Up to } 90.7 \mathrm{~kg} \\
(200 \mathrm{lb})\end{array}$ \\
\hline $\begin{array}{l}\text { IBV: Instituto de Biomecánica de } \\
\text { Valencia }\end{array}$ & $\begin{array}{l}250 \mathrm{~mm} \\
(9.8 \mathrm{in}) \\
\end{array}$ & $\begin{array}{l}\text { Up to } 200 \mathrm{~kg} \\
(441 \mathrm{lb})\end{array}$ \\
\hline Leica Geosystems & $\begin{array}{l}1800 \mathrm{~mm} \text { high } \\
(70.9 \mathrm{in})\end{array}$ & $\begin{array}{l}\text { Not Applicable } \\
\text { (hand held) }\end{array}$ \\
\hline Netvirta & $\begin{array}{l}\text { up to } 2000 \mathrm{~mm} \text { high } \\
\text { (78.7 in) }\end{array}$ & $\begin{array}{l}\text { Not Applicable } \\
\text { (hand held) }\end{array}$ \\
\hline Occipital & $\begin{array}{l}400 \mathrm{~mm} \text { high } \times 3500 \mathrm{~mm} \text { wide } \\
(15.7 \times 137.8 \mathrm{in})\end{array}$ & $\begin{array}{l}\text { Not Applicable } \\
\text { (hand held) }\end{array}$ \\
\hline Paromed & $\begin{array}{l}200 \mathrm{~mm} \\
(7.9 \mathrm{in})\end{array}$ & $\begin{array}{l}\text { Up to } 130 \mathrm{~kg} \\
(286.6 \mathrm{lb})\end{array}$ \\
\hline Precision 3D & $\begin{array}{l}350 \times 170 \times 170 \mathrm{~mm} \\
(13.8 \times 6.7 \times 6.7 \mathrm{in})\end{array}$ & $\begin{array}{l}\text { Up to } 200 \mathrm{~kg} \\
(441 \mathrm{lb})\end{array}$ \\
\hline Shenzhen 3DOE Technology & $\begin{array}{l}350 \times 170 \times 150 \mathrm{~mm} \\
(13.8 \times 6.7 \times 5.9 \mathrm{in}) \\
\end{array}$ & $\begin{array}{l}\text { Up to } 150 \mathrm{~kg} \\
(330.7 \mathrm{lb})\end{array}$ \\
\hline Shining 3D & $\begin{array}{l}300 \times 170 \mathrm{~mm} \\
(11.8 \times 6.6 \mathrm{in})\end{array}$ & $\begin{array}{l}\text { Not Applicable } \\
\text { (hand held) }\end{array}$ \\
\hline STT Systems & $\begin{array}{l}250 \mathrm{~mm} \\
(9.8 \mathrm{in})\end{array}$ & $\begin{array}{l}\text { Up to } 200 \mathrm{~kg} \\
(441 \mathrm{lb})\end{array}$ \\
\hline TechMed3D & Unlimited & $\begin{array}{l}\text { Not Applicable } \\
\text { (hand held) }\end{array}$ \\
\hline Thor3D & Information not available & $\begin{array}{l}\text { Not Applicable } \\
\text { (hand held) }\end{array}$ \\
\hline Trnio & $\begin{array}{l}\text { up to } 2000 \mathrm{~mm} \text { high } \\
\text { (78.7 in) }\end{array}$ & $\begin{array}{l}\text { Not Applicable } \\
\text { (hand held) }\end{array}$ \\
\hline Volumental & $\begin{array}{l}200 \text { to } 300 \mathrm{~mm} \text { high } \\
\text { (7.9 to } 11.8 \mathrm{in} \text { ) }\end{array}$ & $\begin{array}{l}\text { Up to } 65 \mathrm{~kg} \\
(143.3 \mathrm{lb})\end{array}$ \\
\hline Vorum & Unlimited & $\begin{array}{l}\text { Not Applicable } \\
\text { (hand held) }\end{array}$ \\
\hline
\end{tabular}




\subsection{Time to scan and file saving}

Table 7 presents scan times and file saving formats, by vendor. The hand-held scanners usually take the longest time to capture 3D scans, as they have to carefully "wave" around the object (360\%). Most scanners can save scans in OBJ and/or STL formats, except the Anatomi Metrix, Artec, Leica Geosystems models. For designers, the OBJ and STL formats are most useful with measurement software and CAD programs.

Table 7. 3D Scanning time and file saving format, by vendor.

\begin{tabular}{|l|l|l|}
\hline Vendor Name & Time to Scan & File Saving Format \\
\hline 3D Footbank by Dream GP & 15 seconds & OBJ/STL/DXF \\
\hline 3DMD & .0015 seconds & OBJ/STL \\
\hline Anatomi Metrix & .03 seconds & DAS \\
\hline Aetrex Technology & 10 seconds & OBJ/STL/PLY \\
\hline Artec & 30 to 60 seconds & AOP/ASCII/E57/OBJ/PLY/STL/WRL \\
\hline FlicFit & 10 seconds & OBJ/STL/DXF \\
\hline $\begin{array}{l}\text { Global Inspection Solutions/3D3 } \\
\text { Solutions }\end{array}$ & 1.3 seconds & OBJ/STL/DXF \\
\hline Hewlett-Packard (HP) & $<1$ second & STL \\
\hline Human Solutions & 7 seconds & OBJ/STL \\
\hline $\begin{array}{l}\text { IBV: Instituto de Biomecánica de } \\
\text { Valencia }\end{array}$ & 60 seconds & OBJ \\
\hline Leica Geosystems & 10 seconds & DXF \\
\hline Netvirta & 2 minutes & STK/OBJ/STL \\
\hline Occipital & 30 to 60 seconds & STK/OBJ/STL \\
\hline Paromed & 12 to 25 seconds & OBJ/STL \\
\hline Precision 3D & 4 seconds & STL/VRML/DXF \\
\hline Shenzhen 3DOE Technology & 10 seconds & OBJ/STL/ASC \\
\hline Shining 3D & 30 to 60 seconds & ASC/OBJ/PLY/STL \\
\hline STT Systems & 10 seconds & OBJ/STL \\
\hline TechMed3D & 15 to 20 seconds & OBJ/STL/PLY \\
\hline Thor3D & 30 to 60 seconds & OBJ/STL/PLY \\
\hline Trnio & 2 minutes & STL \\
\hline Volumental & 5 seconds & OBJ/STL \\
\hline Vorum & 30 to 60 seconds & OBJ/STL \\
\hline
\end{tabular}

\subsection{Scan resolution and color capture}

The most inconsistent attribute information shared by vendors, pertained to the resolution of their 3D scanners. A large variety of responses were shared; some of them were vague (e.g., high resolution, with no measure), and some had limited research to validate their resolution claims. Color capture (including texture mapping), is also presented in Table 8. 
Table 8. 3D Scan resolution and color capture, by vendor.

\begin{tabular}{|l|l|l|}
\hline Vendor Name & Scan Resolution & Color Capture \\
\hline 3D Footbank by Dream GP & High resolution & Yes \\
\hline 3DMD & Submillimeter resolution & Yes \\
\hline Anatomi Metrix & Submillimeter resolution & No \\
\hline Aetrex Technology & 4,000 pixels & Yes \\
\hline Artec & 1.3 megapixels & Yes \\
\hline FlicFit & High resolution & Yes \\
\hline $\begin{array}{l}\text { Global Inspection } \\
\text { Solutions/3D3 Solutions }\end{array}$ & 64 Megapixels $(8,000$ texture maps $)$ & Yes \\
\hline Hewlett-Packard (HP) & High Resolution $+-0.5 \mathrm{~mm}$ & Yes \\
\hline Human Solutions & High Resolution $+-0.5 \mathrm{~mm}$ & No \\
\hline $\begin{array}{l}\text { IBV: Instituto de Biomecánica } \\
\text { de Valencia }\end{array}$ & High Resolution within $1 \mathrm{~mm}$ accuracy & No \\
\hline Leica Geosystems & High Resolution $+-0.25 \mathrm{~mm}(800 \times 480$ pixels $)$ & Yes \\
\hline Netvirta & High Resolution $+-0.5 \mathrm{~mm}$ & Yes \\
\hline Occipital & VGA $(640 \times 480$ pixels $)$ & Yes \\
\hline Paromed & High Resolution $+-0.5 \mathrm{~mm}$ & Yes \\
\hline Precision 3D & High Resolution $+-0.5 \mathrm{~mm}$ & Yes \\
\hline Shenzhen 3DOE Technology & 4,000 pixels & No \\
\hline Shining 3D & Information not available & Yes \\
\hline STT Systems & High resolution $(752 \times 480$ pixels $)$ & No \\
\hline TechMed3D & High Resolution $+-0.5 \mathrm{~mm}$ & Yes \\
\hline Thor3D & 1.3 Megapixels & Yes \\
\hline Trnio & High Resolution $+-0.5 \mathrm{~mm}$ & Yes \\
\hline Volumental & +-2 mm & No \\
\hline Vorum & High Resolution $+-0.1 \mathrm{~mm}$ & Yes \\
\hline
\end{tabular}

\subsection{Scanner price}

Vendors reported a wide range of prices associated with their 3D scanners. Several vendors were reluctant in discussing price, as they sought to negotiate each and every sale. Few of them had definitive, clear prices - except for the vendors that produced smaller hand-held devices. To provide vendor confidentiality, a price code (Table 9) was developed to report ranges of scanner prices. Table 10 presents prices by vendor.

Table 9. Scanner price codes (in USD).

\begin{tabular}{|c|c|c|c|}
\hline Under $\$ 10,000$ & $\$ 10,000$ to $\$ 19,999$ & $\$ 20,000$ to $\$ 29,999$ & Over $\$ 30,000$ \\
\hline 4 & 47 & $4+4$ & $4+47$ \\
\hline
\end{tabular}


Table 10. 3D scanner price, by vendor.

\begin{tabular}{|l|l|}
\hline Vendor Name & Price \\
\hline 3D Footbank by Dream GP & \\
\hline 3DMD & \\
\hline Anatomi Metrix & \\
\hline Artec & \\
\hline FlicFit & \\
\hline Global Inspection Solutions/3D3 Solutions & \\
\hline Hewlett-Packard (HP) & \\
\hline Human Solutions & \\
\hline IBV: Instituto de Biomecánica de Valencia & \\
\hline Leica Geosystems & \\
\hline Netvirta & \\
\hline Occipital & \\
\hline Paromed & \\
\hline Precision 3D & \\
\hline Shenzhen 3DOE Technology & \\
\hline Shining 3D & \\
\hline STT Systems & \\
\hline TechMed3D & \\
\hline Thor3D & \\
\hline Trnio & \\
\hline Volumental & \\
\hline
\end{tabular}

\section{Conclusion}

Through the use of the 3D HSAF, information was gathered, in order to share the current scanning equipment landscape to other researchers interested in hand anthropometry. The technology landscape is evolving so quickly today, that it is possible new scanners have debuted since the data were collected. It is also possible that some scanners were missed, as mentioned some vendors did a very poor job of communicating their products and capabilities. Nevertheless, keeping track of products in the 3D scanner space through the 3D HSAF is beneficial and could be updated annually to keep researchers accurately informed.

So, what can vendors do? There is a need for consistent communication of scanner attributes between vendors. The researchers suggest developing a more consistent method of explaining metrics and units, so it is easier to weed through the information. Share all the scanner's attributes. If researchers cannot find information about a particular scanner - it "raises a red flag." It says something is hidden, or there may be technological glitch. This makes researchers reluctant to invest. Make the information clear, make it available on public websites, make it easy to understand. 
There are also obvious technology gaps presented in this research that can direct future scanner development. For vendors that have existed for over 10 years, it may be advantageous to develop hand-held scanners or ones that operate off of a mobile device - as researchers are keen to collect data beyond their laboratories. Perhaps collaborating with another company could be beneficial, effective and improve sales. For 3D hand anthropometric studies, if the scanner cannot accurately and clearly collect any subject's hand/wrist, in color, with details and landmarks - then it is not worthwhile investment.

As for the 3D HSAF, there are secondary attributes that could be added to further understand scanner capabilities, including: wireless, tripod, rotating table, robotic arm, USB, Wifi, Bluetooth, SD card and ethernet features. The 3D HSAF could also be re-developed for other types of 3D scan studies (e.g., body and foot). In reality, no matter what type of 3D scanning research is being conducted - it is very difficult to find accurate information without spending a lot of time doing research. Ultimately, the researchers strive to help others find the right scanner products by giving them the context and guidance they need to make informed purchases.

\section{Acknowledgement}

The authors would like to thank the 3D scanner vendors who provided information for the study. The transparency of this information is imperative to the success of research in this space and future development of new, innovative products.

\section{References}

[1] Bertillon, Alphonse. Identification anthropométrique: instructions signalétiques. Vol. 1. Impr. administrative, 1893.

[2] Sokolowski, Susan L., Linsey Griffin, Robin Carufel, and Nokyeon Kim. "Drawing Hands for Glove Design: Does the Data Match-Up?." In International Conference on Applied Human Factors and Ergonomics, pp. 68-77. Springer, Cham, 2018.

[3] Habibi, Ehsanollah, Shiva Soury, and Akbar Hasan Zadeh. "Precise evaluation of anthropometric 2D software processing of hand in comparison with direct method." Journal of medical signals and sensors 3, no. 4 (2013): 256.

[4] Griffin, Linsey, Susan Sokolowski, Heajoo Lee, Emily Seifert, Nokyeon Kim, and Robin Carufel. "Methods and Tools for 3D Measurement of Hands and Feet." In International Conference on Applied Human Factors and Ergonomics, pp. 49-58. Springer, Cham, 2018. 